\title{
Branding European countries in the aftermath of important political transitions
}

\author{
Cornelia ZEINEDDINE \\ The Bucharest University of Economic Studies, Bucharest, Romania \\ cornelia.epuras12@gmail.com
}

\begin{abstract}
Given the intensification of the regional economic integration, innovations in the digital technology and transportation infrastructure, the business environment has become highly globalized. In the globalized marketplace, there is one tool that helps countries distinguish themselves, namely nation branding. Nation branding plays a crucial role in attracting investments, boosting exports and increasing the number of tourists and foreigners (workforce and investors alike). Having in mind the importance of understanding the course of history's new challenges and opportunities, posed by the increased internationalization of the marketplace, the paper looks into efforts made by some European countries in nation branding. An adequate policy of nation branding becomes even more important for certain countries that have passed through important political transitions. Enacting coherent and comprehensive nation brands is essential for the benefit of such transitions. The study explores European countries who transitioned form state-dominated to market economies. As a result, their branding strategies had to be consolidated, while being confronted with important political gambits. The processes undertaken in the quest for nation and place branding and the challenges met by these countries represent the focal point of the analysis. This study overviews the salient challenges, together with inherent mistakes in the attempt of nation branding, at the same time with highlighting the positive facets of the process. Branding countries in the part of Europe that has been shaken by political transitions has been evolving for more than two decades and their practices allows us to pinpoint communalities, challenges and paradigms of nation branding in Europe.
\end{abstract}

Keywords: nation branding, place branding, Europe, transition.

\section{Introduction}

The paper studies the increased importance given to nation branding ever since the fall of the Iron Curtain in a specific region- the so-called Eastern European bloc. The practice of nation branding is sustained and encouraged globally by public or private sector organizations. The process of conceptualizing nations under the framework of a brand has gained recognition in an increasingly globalized marketplace. Globalization itself as a phenomenon assumes the dilution of the idea of nation-state. It popularized the practice of liberalizing property and services, reducing trade barriers and emerging markets with global trading.

Nation branding has become an integrated part of globalization. How can we define it? Has nation branding borrowed the corporate practices of marketing? The brand constitutes a relationship between the buyer and seller, implying a certain value you attach to a product (Lynch and de Chernatony, 2004). The analogy with a similar practice between products and nations is not straight clear, as nation branding implies additional elements beyond pure marketing practices. Nation branding is a complex, multilayered process, nations representing the story of complexity of identity dispersed among some historical events that shaped nations. In sum, nation branding renders some aspects (it should take 
note of the most vigorous ones) of a country and its identity, boosting the chances to be given more recognition by virtue of the awareness gains (at international level). It should result in a better positioning in the international markets.

The paper will highlight the construction of nation branding in Central-Eastern Europe, presenting particularities at European level through the example of Estonia and Poland. The paper concludes by drawing some lines about the process in this part of the world and the practices it generated.

\section{Literature review}

\section{Nation branding- a cross-disciplinary category}

Nation branding as a distinctive category in scientific literature is quite recent, even though the essence of it is not. It has emerged as a modern-day phenomenon, as many nations are now making use of brand management techniques in order to consolidate their position on the world stage (Dinnie, 2008). The nation branding can present many benefits, hereby including socio-cultural-economic opportunities. They are of increasing importance in the current context -i.e. globalization- where the idea of state is diluted and the links/networks between nations are of utmost importance. Place and destination branding precede the efforts made in the sense of nation branding (Kotler, Haider \& Rein, 1993). Olins' Trading Identities (1999) set a milestone in the discussions vis-à-vis nation branding. Simon Anholt fathered nation branding as a concept singularly and became a prolific author (2005; 2007), being an apologist of nation branding and its cumulative effect, whom he called competitive advantage. In addition, he argues that the process is overlapping different segments of communication, identity and management "branding (a nation) is a process of designing, planning, and communicating the name and the identity, in order to build or manage the reputation (of a country)" (Anholt, 2005).

In his vision, nation branding is formed by six areas through which nations work willingly or accidentally - (Anholt, 2007): "tourism, exports, governance, investment and immigration, culture and people". These elements are ideally fulfilled cumulatively, only then reaching the level of competitive advantage. 


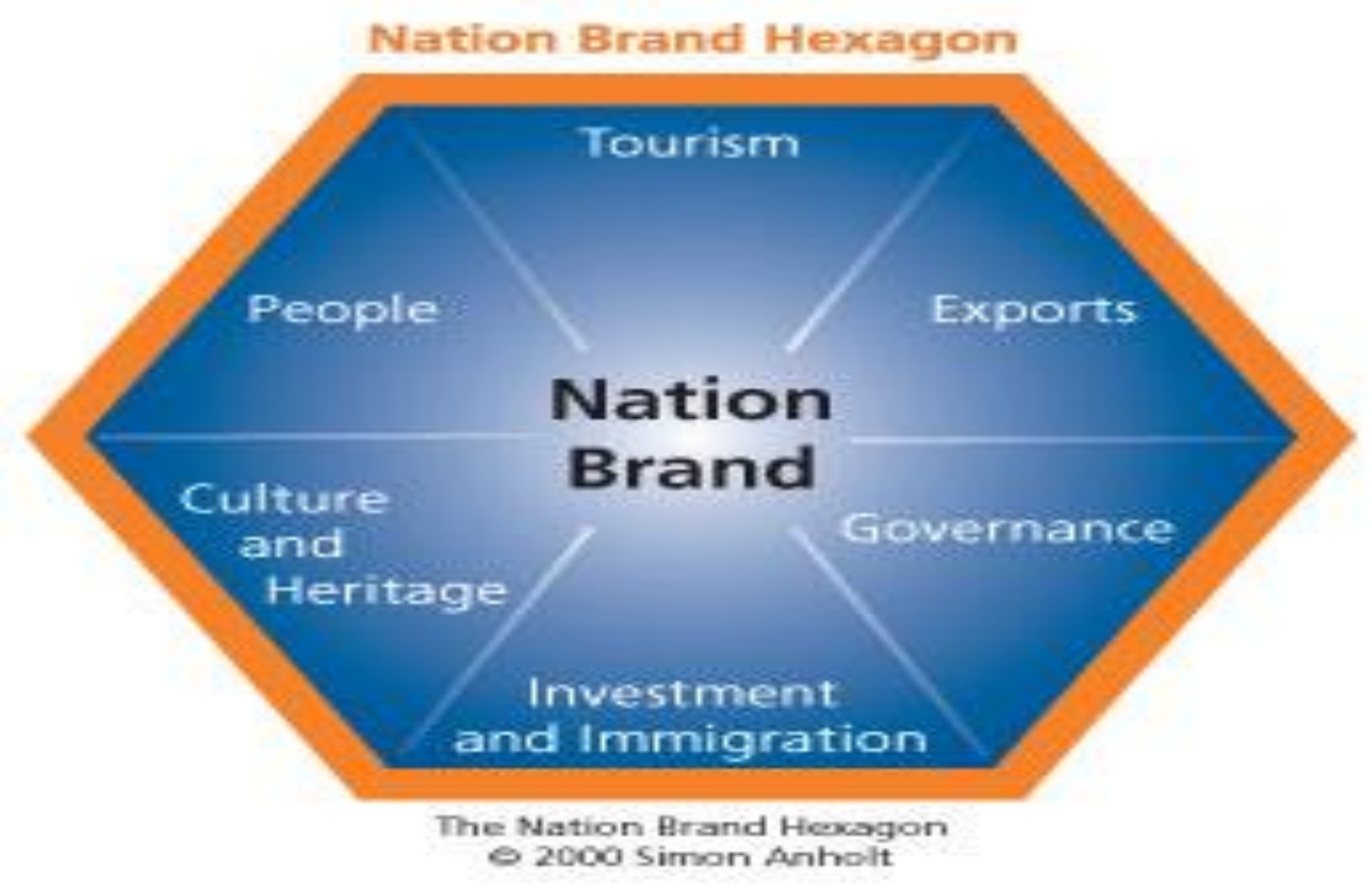

PICBE $\mid 1061$

Figure 1. Nation Brand Hexagon/ Simon Anholt, 2000

Anholt added ulterior to the six-layer figure, namely, the leaders' positioning / leverage on international stage (Anholt, 2007). Nevertheless, nation branding remains multi-layered and more complex than Anholt's paradigm. Why it matters? Considering that nation branding has a "direct and measurable impact" in what the international status is concerned, it reaches out to the domains of international relations, public diplomacy and economy altogether (Anholt, 2007).

Nation branding is not making national identity vanish, even though it spurred in the context of globalization, but it makes some features of the nation visible at international level. Against the odds, nation brands preserve the national complexity (Kotler and Gertner, 2002). Nation branding combines both theory and practices that deal with the entire nation rather than a single commercial product or service. Given this complexity, we need a comprehensive and systematic approach when establishing the strategy of nation branding (Anholt 2007; Caldwell and Freire 2004).

We stated from the beginning that nation branding is more complex than product branding since it implies a multidimensional nature of the branding and involves multiple stakeholder groups (Dinnie, 2008). Gnoth (2002) entails that the process of nation branding is easier than product branding, given that a nation is submitted to the influence of uncontrollable events, whereas a product brand depends on a company for its existence and promotion. In addition, nation branding is a more expansive process, implying different layers and elements, and it is obviously multidisciplinary- its valences ranging from public diplomacy and international relations to marketing and sociology (Fetscherin, 2010; 
Anholt, 2002, 2010). One distinctive element when compared to ordinary product branding is that political events or terrorist attacks, or any other incident with negative connotation can alter the attributes of a country (Caldwell and Freire, 2004), together with governmental adjustments -for better or worse (Fetscherin, 2010).

In addition, we have to think of a nation's reputation. A product will not suffer the same perception as a nation. Anholt (2008) considers that stereotyping is altering the real projections of nations. Both positive and negative stereotypes unfortunately, even though they rarely reflect the reality, they have an impact on receptiveness of people towards a nation brand.

In order to be prepared to face the challenges of stereotyping, one has to envisage a nation branding strategy that follows the specialists' advice. Dinnie (2009) argues that a nation brand is a unique, "multi-dimensional blend of elements" that distinguishes the components of a nation. Nation branding has objectives that go beyond the international image. The ultimate goal is that through nation branding one can attract tourists, develop the economy and investments, and create positive projections that result in acceptance and openness to the markets (Fetscherin, 2010).

We should pass on to examine the characteristics of two nation brands in a sui generis construction, namely the European Union (EU). Within the European construction, states accept to give away part of their sovereign rights, following a common security and policy framework and a certain set of predetermined rules. However, nation branding does not interfere with this specificity. Given that being a member of the EU means you fulfill certain standards, the nation branding can only potentate the effects of being a member of the EU.

\section{Methodology}

The paper compares the attempts of nation branding in two Central-Eastern European countries, correlating this process with a political transition. The research follows a qualitative pathway, noting the evolutions in the field of nation branding. The research in this specific domain flourished in the past two decades. The paper investigates the specificity of political turnovers in a specific region and its effect on nation branding process.

\section{Brand Estonia}

We chose for examining the individual case of Estonia for various reasons. Anholt (2007) believes nation branding is a particularly positive instrument for small countries, being the case of Estonia. Branding can be extremely useful to small countries, as he stated that "second world transition economies" could benefit most from this practice. "Having strong and well-known export brands enables both companies and countries to punch above their weight" (2007).

Another reason why Estonia makes a case for the paper is that it is a small country of approximately 1.4 million people, which was the first former Soviet state to launch a comprehensive branding campaign. 
Estonia gained independence from the USSR in 1991. The transition generated both challenges and opportunities. The transition in the economic field meant to create an open environment from a state controlled mechanism. The Estonians relaunched their national identity and worked towards accession to the global markets. Estonia joined the EU in 2004 and it is member of the Eurozone since January 2011. The nation (re)branding approach was interlinked with the liberalization of the economy. "It results from the assumed PICBE $\mid 1063$ economic model, which applies to the concept of nation branding" (Raftowicz-Filipkiewicz, M., 2012)

Estonia acknowledged the opportunities nation branding offers. The government was actively involved in the process and its implementation. Therefore, Brand Estonia was initiated at the hands of the Ministry of Economic Affairs via one of its agencies in 2000 with a view to economic development (Pawlusz, Polese, 2016). The initiative was part of a larger structure that aimed to bolster opportunities for tourism, investors and citizens alike. An Estonia marketing firm -Emor- was involved in the designation of the brand. The main challenge was to place Estonia on the international map for precise constituency: tourists, foreign investors, and export markets.

The challenges were extremely high, for very particular reasons. For example, foreigners have difficulties in locating Estonia and confuse it with the other Baltic neighbors. Estonia had produced several slogans for the sake of communicating its identity "a Nordic country with a twist", "a nation that is as progressive and hip as it is historyfilled", "the new Scandinavia", and an "IT-nation" (Pawlusz \& Polese, 2016). Finally, the one that captured most the essence of Estonia of the new millennium is the IT industry. Currently the brand e-Estonia is a shortcut name that identifies Estonia's successful narrative for "digital solutions in government, public management, business, education, etc. "(www.balticworlds.com)

The construction of a brand for Estonia overlaps with its process to join the EU, the development of an incipient tourist industry and investments. Estonia had the chance to host the Eurovision Song Contest in 2002. The possibility to be one of the most widely viewed television shows in Europe marked an important step in the sense of visibility (Gardner \& Standaert, 2003). What are the methods for small countries to "sell" themselves to the world? What kind of message can they convey, as the competition in the international marketplace is challenging?

The nation brand promotion is something that should be relatively simply structured. Olins (1999) outlines a seven-step process, among whom he mentions consultation of the leaders with other stakeholders in order to identity both strong and weak points. Ulterior you build the central idea; develop the main visual theme, which is attached to all visual representations. All these factors are to be correlated in a message adjusted to target audiences: tourists, internal and external investors. Estonia managed to sell well the image of an IT nation, being one of the successful brands of the former Soviet countries (if we may say so, the most successful). Concomitantly, it represents a successful transition to a modern view of nation branding practices in the aftermath of a complex political change. 
Simon Anholt proposed six channels for nation branding. In our assessment, Estonia could tick most of them, except immigration and people, and partly culture and heritage as they are not known worldwide for a specific characteristic/ identity/ heritage and the immigration quotas to Estonia are relatively low (https://www.politsei.ee/en/teenused/residence-permit/).

\section{Brand Poland}

Starting the late 1990 s and particularly at the beginning of the $21^{\text {st }}$ century, nationbranding idea has become popular around the world or, as van Ham (2002) labelled the phenomenon, we are witnessing a "brandology business". States realized soon that the national image has a strong impact on consumers of local or international origin, investors and could bolster or diminish the soft power effect. It is about a balance between PR, marketing and public diplomacy. Poland, one of the biggest countries of Central-Eastern Europe has not been spared from the process.

Poland is a country in Central Europe, part of the former Eastern bloc under the influence of the Soviet Union until 1989 (and not part of the Soviet Union itself, as Estonia). There are a number of factors indicating that Poland needs emphasis on nation branding. The pressing aspects come from the exterior and play a crucial role in shaping the future of Poland: globalization trends, challenges generated through the accession process to the EU, the harsher economic competition, as the export markets extended beyond the neighborhood, neighbors with whom there is an increased competitiveness (Florek, 2005).

Unlike the case of Estonia, which struggled for recognition, when the European Commission made its research (Flash Eurobarometer 140) revealed that Poland, together with Hungary and the Czech Republic were "best known" among the countries that acceded to the EU in 2004, and were identifiable by the citizens of other member states. These three countries are the most representative countries of the 2004 wave in terms of population too- counting $80 \%$ of the population of the countries that joined the EU in 2004.

Unlike Estonia, which had difficulties in being associated with a certain location or distinctiveness, in the investigations carried within Poland, foreigners were more likely to associate Poland with the following specificities: "with low prices (11.3 per cent), alcohol and a high level of education (6.7 per cent)"(Mielewczy\& Czuba, 2011). The largest part of respondents labeled vodka as the most symbolic product of Poland (Mielewczy\& Czuba, 2011) (25.0 per cent of all mentions).

Poles, as a nation are associated with piety and struggles throughout their history, which is something more specific than in the case of Estonia. In terms of governance, the progress was obvious. Just like Estonia, Poland has enacted a transformation of the political system that resulted in membership of NATO and the EU. On the other hand, some negative stereotypes related to corruption, crime, dishonesty persist. Poland could not come up with something as positive as the image of the IT nation as Estonia did. However, there have been deep changes that should be incorporated in the nation brand. There was an opening of the economy and people and investments flourished, the region observing a dynamic economic growth. Foreigners started to come visit and discover the heritage of cities like 
Warsaw or Krakow. Poland ranks better in terms of culture and heritage than the small country of Estonia. It could even outdo itself. There remain touristic destination such as the coastal line and other historic cities, especially Gdansk that need more place/destination branding. Marketing places is a subsidiary concept to the nation brand that is particularly beneficial for tourism and investments (Caldwell and Freire, 2004). The image of a place plays a crucial role in the decision process of tourists and investors alike. Kotler and Gertner (2002), argue that strategic place branding augments a country's positioning in the competitive international market. It calls upon a specific target and objectives that need to be implemented. The entire process is affecting organization at all levels and involves different stakeholders of the society in the constructions of attractions and the required infrastructure (de Chernatony, 2007). In the tight competition in the global marketplace, you need to find distinction and uniqueness (Caldwell and Freire, 2004). A niche that functioned well in the case of Estonia is the association with e-Estonia. Poland is striving in the compartment of music - the country of Chopin, which confers a romanticized projection. But the intermittent governance problems and the apparent lack of consensus between government and population are altering the entire process (Stysowie, 2004).

In addition, in the branding process, citizens should be a part of the construction of that distinctive blend (Payne et al., 2009) or as Anholt remarked that, the citizens should live the brand (Anholt, 2006).

Unfortunately, A. and S. Stysiowie (2004) perceive Poland as going through division and disparity between the stakeholders involved in a normal nation branding process and the situation is constantly deepening. The attentiveness to details, hereby including reputational risks and to the coherence of the communication are crucial in the success of a nation brand (Anholt, 2005; Dinnie, 2008). However, if we follow Anholt's hexagon, Poland can be deemed as a quite successful brand, with notable improvements over the past two decades. Despite the fact it has to work on some governance aspects, it is doing well economically (especially in investments area and exports), it revived part of its old culture and heritage resulting in attractions for tourists. Moreover, Polish people benefit from a certain distinctiveness (for piety and resilience throughout history).

For Poland as for Estonia, the success of the transition is obvious as they joined the select EU and NATO club, the governance element playing an important role in this respect. However, the challenges are yet to be overcome. These countries as the entire Eastern bloc would need stronger nation brands void of the negative perceptions that linger along the name of the region in order to bolster the international positioning.

\section{Results and discussions}

As a conclusive remark, a nation needs visibility, with a view to reach that competitive advantage Anholt was talking about. The logic first step is to generate awareness. A country, which is virtually unknown, cannot be branded (see the case of Estonia at the beginning of the nation branding process). Moreover, it is essential to involve people and stimulate their emotions, especially regarding perceptions vis-à-vis the process ("citizens should live the 
brand"-see above). In addition, in terms of stereotypes, a brand suffers a high impact in relation with positive or negative images.

The process of nation branding consisting of long term planning of a strategy for a country's reputation and its effective management. It is made up of activities that ultimately generate increased competitiveness. A nation brand needs a well-thought strategy. Advertisement and communication are only a small part of the picture, allowing at most an effect with little sustainability (Dinnie, 2008). A structured and comprehensive approach goes beyond logos and visual messages. The sound planning of a nation brand leads to a competitive advantage, revealed in economic indicators of the country. Anholt (2007) believes it is nation branding that makes a nation's features robust and visible.

Within the European Union, it is almost implied that we blend both global and local interests, more than in any other entity. In 2013, the enlargement marked peak number of 28 members (currently the UK is in the process of withdrawal, representing a premiere) and a population of around 500 million people. For the Central and Eastern European countries, the new members of the EU club, the European Union opened the path for new opportunities of development (actually the process of joining the EU was overlapping the construction nation brands) and new financial instruments that can be seized for nation branding. However, nation branding cannot be a process that overcomes overnight the difficulties of the past.

\section{Conclusion}

In the case of Central and Eastern European countries, the problems related to reputation, stereotypes and the lack of social consensus remain visible. The past legacy has not been overcome completely. The region has developed economically substantially, but a one-sided perspective may prevail, namely that they are post-communist countries. The communism has been associated with inferior quality of products, work inefficiency and corruption. The negative image is inherited, even though indicators show a dynamic economy (more than the Western ones sometimes). One can identity another regional similarity for the countries examined, notably in the cases of small countries, such as Estonia and the Baltic counterparts (less valid for Poland) is the lack of publicity at international level. This renders the picture for these countries bleaker than it really is (Olins, 2004). This state of anonymity aids the diffusion of negative stereotypes. Moreover, lacking support from behalf of subsequent governments and the lack of vision of the country's development. In conclusion, the process has still many steps ahead before it reaches success. Nevertheless, it demonstrates that a transition can generate good opportunities for revamping an image and re-designing governance, with long-lasting effects on nation-brands, including here being part of a prosperous regional structure (the EU).

\section{References}

Anholt, S. (2000). The nation as a brand. Across the Board. 37 (10), pp. 22-27. 
Anholt, S. (2005). Brand New Justice, Oxford, UK: Butterworth-Heinemann.

Anholt, S. (2006). Public diplomacy and place branding: Where's the link? Journal of Place Branding, 2 (4), pp. 271-275.

Anholt, S. (2007). Competitive identity: The new brand management for nations, cities and regions. New York: Palgrave Macmillan.

Anholt, S. (2008). From nation branding to competitive identity - The role of brand management as a component of national policy. In K. Dinnie (Ed.), Nation branding: concepts, issues, practice (pp. 22-23). Oxford, UK: Butterworth-Heinemann.

Anholt, S. (2010). The importance of national reputation. Accessed from: www.fco.gov.uk/en/about-us/publications-and-documents/publications1/pdpublication/national-reputation.

Caldwell, N. and Freire, J.R. (2004). The differences between branding a country, a region and a city: applying the Brand Box model, Brand Management, 12 (1), pp. 50-61.

de Chernatony, L. (2007). From Brand Vision to Brand Evaluation. The Strategic Process of Growing and Strengthening Brands, Amsterdam: Elsevier.

Dinnie K. (2008). Nation branding, concepts, Issues, Practice, Oxford: Elsevier.

Dinnie, K. (2009). Nation Branding: Concepts, Issues, Practice, Oxford: Elsevier.

Fetscherin, M. (2010). The determinants and measurement of a country brand: the country brand strength index, International Marketing Review, 27(4), pp. 466-479.

FLASH EUROBAROMETER 140. Enlargement of the European Union. SURVEY: 21/03/2003 to 30/03/2003 ANALYTICAL REPORT: 11/04/2003.

Florek, M. (2005). The country brand as a new challenge for Poland, Place Branding; Houndmills, 1(2) (Mar), pp. 205-214.

Gardner, S. \& Standaert, M. (2003). Estonia and Belarus: Branding the Old Bloc. Brand Channel.

Gnoth, J. (2002). Leveraging export brands through a tourism brand, Journal of Brand Management, 9(4/5), pp. 262-280.

Kotler, P. and Gertner, D. (2002). Country as brand, product, and beyond: a place marketing and brand management perspective, Journal of Brand Management, 9(4/5), pp. 249261.

Kotler, P., Haider, D. and Rein, I. (1993). Marketing Places: Attracting Investment, Industry, and Tourism to Cities, States, and Nations. New York: The Free Press.

Lynch, J. and de Chernatony, L. (2004). The power of emotion: brand communication in business-to-business markets, Journal of Brand Management, 11(5), pp. 403-419.

McDonald, M. (2007). Marketing Plans. How to Prepare Them, How to Use Them, Amsterdam: Elsevier.

Olins, W. (1999).Trading Identities: Why Countries and Companies are taking on each others' Roles, The Foreign Policy Centre, London, UK.

Olins, W. (2002). Branding the nation -- The historical context, The Journal of Brand Management, 9 (4-5) , pp.241-248.

Olins W. (2004). Wally Olins o marce, Instytut Marki Polskiej, Warszawa.

Pawlusz, E., Polese, A. (2016). Scandinavia's best-kept secret. Tourism promotion, nationbranding, and identity construction in Estonia (with a free guided tour of Tallinn Airport), The Journalism of Nationalism and Ethnicity, 5 (5), pp.873-892. 
Payne, A., Storbacka, K., Frow, P. and Knox, S. (2009). Co-creating brands: diagnosing and designing the relationship experience, Journal of Business Research, 62(3), pp. 379389.

Dorota Mielewczyk, Tomasz Czuba, (2011). Poland: the brand, Marketing Intelligence \& Planning, Bradford, 29 (1), pp.63-68

Raftowicz-Filipkiewicz, M. (2012). Nation branding as an economic challenge for the countries of the Middle and East Europe on the example of Estonia, Equilibrium; Torun, 7(4), pp. 49-59.

Skinner, Heather; Kubacki, Krzysztof; Moss, Gloria; Chelly, David, (2008). International marketing in an enlarged European Union: Some insights into cultural heterogeneity in Central Europe*, Journal for East European Management Studies; Chemnitz, 13 (3), pp. 193-215.

Stysiowie A., Stysiowie S. (2004). Marketing jako orientacja kierownicza, [in:] L. Garbarski (ed.), Kontrowersje wokól marketingu w Polsce, tozsamosc, etyka, przyszlosc, Wyzsza Szkola Przedsiebiorczosci i Zarzadzania im. Leona Kozminskiego w Warszawie, Warszawa.

Szondi, G. (2007). The role and challenges of country branding in transition countries: The Central and Eastern European experience. Place Branding and Public Diplomacy, 3 (1), pp. 8-20.

Van Ham, P. (2002). Branding territory: Inside the wonderful words of PR and IR theory. Millennium: Journal of International Studies, 31(2), pp. 249-269.

Rene Mäe. THE STORY OF E-ESTONIA. A DISCOURSE-THEORETICAL APPROACH. http://balticworlds.com/the-story-of-e-estonia/

Immigration to Estonia. Accessed from: https://www.politsei.ee/en/teenused/residencepermit/ 